\title{
Of dogs and hookworms: man's best friend and his parasites as a model for translational biomedical research
}

\author{
Catherine Shepherd ${ }^{*}$, Phurpa Wangchuk and Alex Loukas ${ }^{*}$
}

\begin{abstract}
We present evidence that the dog hookworm (Ancylostoma caninum) is underutilised in the study of host-parasite interactions, particularly as a proxy for the human-hookworm relationship. The inability to passage hookworms through all life stages in vitro means that adult stage hookworms have to be harvested from the gut of their definitive hosts for ex vivo research. This makes study of the human-hookworm interface difficult for technical and ethical reasons. The historical association of humans, dogs and hookworms presents a unique triad of positive evolutionary pressure to drive the A. caninum-canine interaction to reflect that of the human-hookworm relationship. Here we discuss A. caninum as a proxy for human hookworm infection and situate this hookworm model within the current research agenda, including the various 'omics' applications and the search for next generation biologics to treat a plethora of human diseases. Historically, the dog hookworm has been well described on a physiological and biochemical level, with an increasing understanding of its role as a human zoonosis. With its similarity to human hookworm, the recent publications of hookworm genomes and other omics databases, as well as the ready availability of these parasites for ex vivo culture, the dog hookworm presents itself as a valuable tool for discovery and translational research.
\end{abstract}

Keywords: Ancylostoma caninum, Human hookworm, Hookworm model, Translational model, Omics

\section{Background}

"His name is not Wild Dog any more, but the First Friend, because he will be our friend for always and always and always." Rudyard Kipling

Over one-third of people on the planet harbour a parasitic helminth [1, 2]. Helminth infections are responsible for a host of morbidities that trap people in a cycle of poverty. Moreover, parasitic diseases kill millions of people each year, primarily in developing countries of the tropics [3, 4]. Over 80 percent of helminth infections are caused by soil transmitted helminths (STH) [5]. Elimination of STH in Western society started in the early 20th century as a result of better sanitation and public sewerage programs [6]. The problem of helminth infections in developing nations was recognised, but it was not until the advent of anthelmintic drugs and the World Health Organisation initiatives

\footnotetext{
* Correspondence: catherine.shepherd1@my.jcu.edu.au;

alex.loukas@jcu.edu.au

Centre for Biodiscovery and Molecular Development of Therapeutics,

Australian Institute of Tropical Health and Medicine, James Cook University, Cairns, Australia
}

(c) The Author(s). 2018 Open Access This article is distributed under the terms of the Creative Commons Attribution 4.0 International License (http://creativecommons.org/licenses/by/4.0/), which permits unrestricted use, distribution, and reproduction in any medium, provided you give appropriate credit to the original author(s) and the source, provide a link to the Creative Commons license, and indicate if changes were made. The Creative Commons Public Domain Dedication waiver (http://creativecommons.org/publicdomain/zero/1.0/) applies to the data made available in this article, unless otherwise stated. attempted [7-10].

As we approached the 21st century, rather than celebrating the worldwide demise of $\mathrm{STH}$, drug failures and incomplete coverage has meant the persistence of this foe. Previously, effective drugs like mebendazole and other benzimidazole anthelmintics are now unable to completely eliminate STH infections [1, 11-18]. Historical evidence suggests that drugs alone will not result in the elimination of STH infection and the development of resistance to benzimidazoles in gastrointestinal nematodes of livestock [19-21] is a major point of concern for human STH infections, due to the reliance on albendazole for human hookworm treatment. Indications are that other means of control should be at the fore of research and development agendas [3, 22-24]. Two such avenues are the identification of new anthelmintic compounds $[25,26]$ and the development of vaccines that are effective against STH [3, 27]. Key to this research is a fundamental understanding of the interactions between helminths and their environments as well as the key signals that helminths require from their hosts 
to facilitate their extraordinary parasitic existence [10]. Characterising parasitic helminths at a deep molecular level will reveal vulnerable pathways that can be exploited by novel drugs $[10,28]$, and molecules of immutable vaccine antigen potential [29,30].

Developing nations are not the only benefactors of hookworm research. Indeed, in developed countries there is an increase in the incidence of autoimmune and allergic diseases that has been linked to lack of exposure to pathogens such as STH [31]. It is apparent from epidemiological studies [32-36] and clinical trials [37, 38] that the immunomodulatory inputs provided by exposure to STH and other pathogens assist in the development and maintenance of a healthy immune system in humans. Characterising helminth-driven immunoregulation at a molecular level will shed light on the aetiology of inflammatory diseases, and may uncover important disease/pathology pathways that can be targeted by helminth-derived therapeutics $[39,40]$.

The identification of a suitable model for the study of such a broad research agenda examining both the benefits of iatrogenic helminth infections and the pathogenesis of STH infections needs to be carefully considered. The benefit is the generation of a large amount of translatable research data coupled with an economy of scientific effort and resources. Fruitful models ideally need to be naturally occurring (i.e. not a human parasite manipulated to survive in experimental animals) and closely resemble the relationship between a STH and its human host. The human-hookworm-dog axis reflects an intimate evolutionary relationship between three organisms, a triad that presents a naturally selected model for integrated research. The dog hookworm, primarily Ancylostoma caninum, is discussed in this context in this review.

\section{Of humans, hookworms and hounds: the relationship between humans, hookworms and dogs is enduring and nuanced}

For thousands of years (estimated to be anywhere between 14,000 and $\sim 35,000$ years [41]) humans and canines have shared the same evolutionary drivers. The process of domestication has resulted in positive selective pressure on dogs to be more like humans for thousands of generations [42-44]. Genetic evidence suggests that dogs were domesticated from wolves [45], with successive domestication events occurring over at least 33,000 years [41]. Importantly, dogs accompanied humans over the threshold from hunter gatherers to agricultural based societies, and this close association with humans has meant that dogs have evolved to tolerate diets rich in starch [46]. Co-habitation between humans and dogs has resulted in shared nutritional, bacterial and pathogenic environments [42, 44, 47], making dogs a natural animal model for human disease [48]. Figure 1 illustrates the triad relationship of hookworms, humans and canines. Sharing environments with each other increases the risk of cross-infection with each other's parasites. We know that Strongyloides, Toxocara, tapeworms and hookworms can be passed from dogs to humans and bidirectional transfer occurs in some cases, acting as pools for reinfection.

\section{Dogs as functional models for human disease}

The parallel evolution between dog and human may have driven the predisposition to autoimmune diseases through antagonistic pleiotropy [41]. Diseases that have underlying similarities to human disease can be utilised for the study of aetiology and treatment. Genetic bottlenecks that have occurred in dog breed conformation have meant that many dog breeds are good models for both monogenic and complex genetic human diseases [48]. For example:

- Nova Scotia duck tolling retrievers develop canine systemic lupus erythematosus which is homologous to human systemic lupus erythematous (SLE) [48]

- Osteogenesis imperfecta (brittle bone disease) in beagles and golden retrievers (polygenic disease) [49, 50]

- A number of dog breeds (Pembroke Welsh corgi, Boxer, Rhodesian ridgeback, German Shepherd dog, and Chesapeake Bay retriever) develop canine degenerative myelopathy, an amyotrophic lateral sclerosis-like disease that has similar underlying genetic basis in humans (sod1 gene) [51]

- Diseases such as narcolepsy [52], cancers [53, 54] and obsessive-compulsive disorder [55] that occur in humans have the same underlying genetic basis in dogs

Diseases like diabetes that occur in both humans and dogs and are polygenic with similar underlying single nucleotide polymorphisms (SNPs) in T helper 2 type cytokines, reflect the complex environmental and genetic sequelae in the development of this disease [56]. Similarly, dilated cardiomyopathy (DCM) is associated with a large number of homologous genes in both humans and canine breeds [57], making these dogs excellent models for the study of this disease in humans. These parallels between human and dog diseases mean that canine models provide identification, diagnostic and therapeutic research opportunities in a naturally occurring animal model.

The case of dogs and inflammatory bowel disease (IBD) is a little more confounding. Dogs with spontaneous IBD have similar symptoms and clinical presentation to humans with the disease $[58,59]$, yet the 


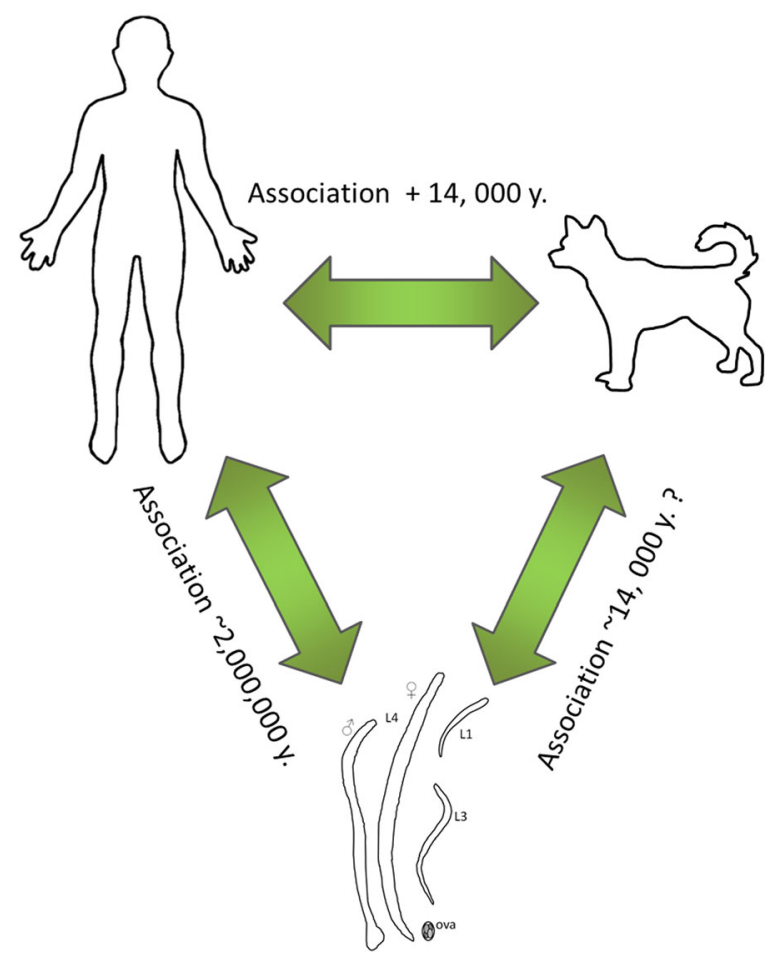

Fig. 1 The human-hookworm-dog relationship is defined by a long association. Positive evolutionary pressure on canines has caused them to adapt to human environments. Hookworms have likely had conflicting immunogenic environments during cross infection events between human and dogs. In the $\sim 14,000$ years of association (conservative estimate) it is theoretically possible to have nearly 73,000 generations of hookworm in this timeframe

underlying basis of these diseases has not been identified. In the case of risk for gluten sensitivity in dogs there has been no link to the major histocompatibility complex (MHC) genes [60], as has been found in humans with celiac disease [61, 62].

Despite the established value of dog-human disease models, canine models are yet to be fully exploited as functional models for human hookworm disease. One exception is the Human Hookworm Vaccine Initiative, which used the A. caninum-dog model [63] for identifying molecules that could be candidates for human hookworm vaccines [3].

\section{Hookworms are a large group of closely related organisms}

In humans, the term "hookworm" is often used to refer to Necator and Ancylostoma interchangeably even though there are a number of distinctions as highlighted in their life-cycles, as described in Fig. 2. These organisms are grouped together on the basis of clinical presentation, the similarity of the organisms (both in appearance and life-cycle) and their success as parasites (Table 1). Physically, hookworms can appear similar, with Necator americanus and Ancylostoma duodenale ova being difficult to distinguish visually. Phenotypic similarities can mean that species that have large genetic separation can appear physically alike, for example $A n c y$ lostoma braziliense and Ancylostoma ceylanicum have identical mouthparts in the adult stage, making it impossible to accurately identify species without genetic tools $[49,50]$. This means previous attributions of pathogenesis and distribution limits may be more complex than assumed, and in some cases flawed [50].

The success of hookworms as parasites hinges on their ability to be well tolerated and adaptive to their hosts. Hookworms as gut dwelling parasites gain their nutrition from their hosts in the form of blood [62, 63]. To do this they attach to and slice through the gut wall where they feed. Ancylostoma is a voracious feeder, estimated to consume between $0.15-0.23 \mathrm{ml}$ blood/worm/ day, whereas Necator consumes $\sim 0.03 \mathrm{ml}$ blood/worm/ day [64]. The host reacting to injury and the presence of the parasite attempts to expel the parasite through innate immune responses such as mucus production, increased peristalsis and eosinophilia [65-67]. Despite this, hookworms are usually well tolerated in a healthy host $[68,69]$ because they actively create an area of immune privilege around the site of their attachment by secreting a suite of immunomodulatory molecules [39, 70-72].

The hookworm genera Ancylostoma and Necator are intimately associated with the history of humanity, and it seems these heirloom parasites have evolved with 


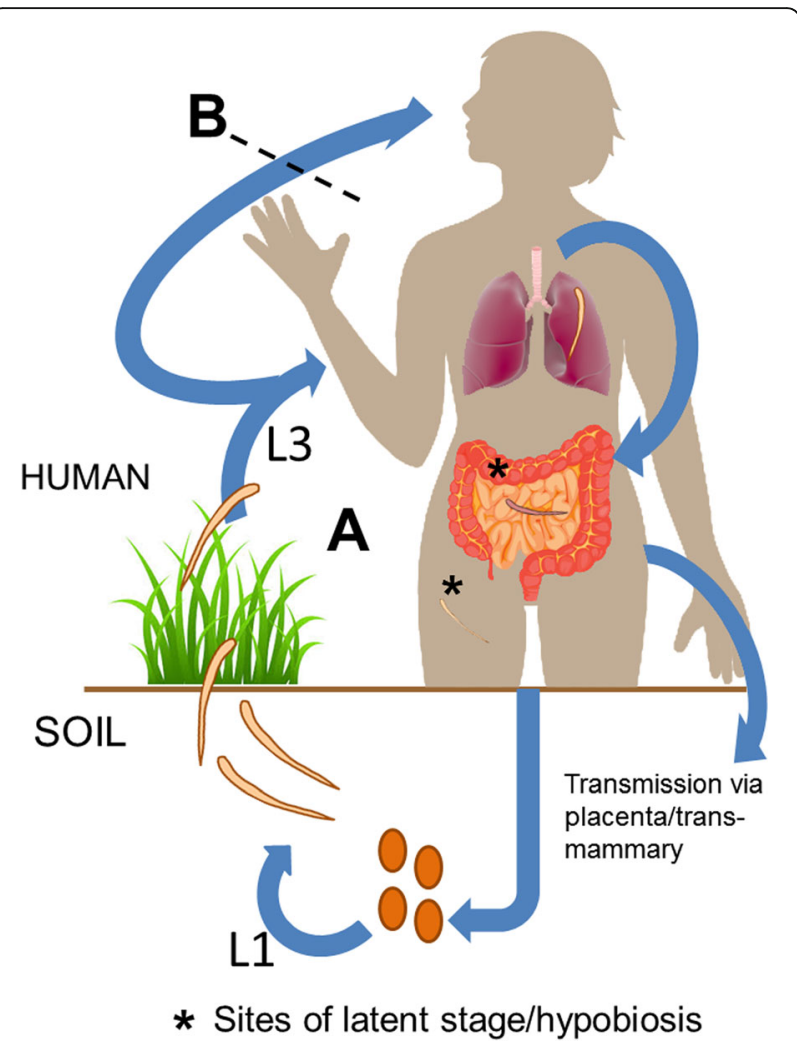

Fig. 2 Hookworm life-cycles. Life-cycle a Ova contained in infected faeces hatch in soil and larvae live freely for up to two moults. Thirdstage larvae (L3) come in contact with skin and penetrate the epidermis. Migrating through the lymphatic and circulatory system they end up in the lung. Larvae mature en route to the upper gastrointestinal tract via the pharynx and become fifth-stage larvae in the duodenum. Once attached to the small intestine they feed, become mature to reproductive capacity and mate. Eggs produced by the female worm are then shed in faeces. Alternatively, the free-living larvae are capable of infection through the oral route. These organisms are capable in some cases of latent stage/hypobiosis and trans-mammary or placental transmission. Life-cycle $\mathbf{b}$ does not include oral transmission. Latent stage/hypobiosis and alternative transfection routes are not reported in these organisms

humans from our primate ancestors [51, 52]. Such is the close relationship that hookworm ova have been used in archaeology to help identify migration routes of humans [51-53] and supports the intertwined immunomodulatory interactions proposed by Rook's “Old Friends Theory" [31]. In a literature survey of Ancylostoma and related species (Table 1), we identified a number of taxonomically related hookworms. These hookworms occur across a wide range of hosts with some species capable of establishing patent infection in dogs, cats, golden hamsters and humans (as is the case for A. ceylanicum). The common dog hookworm (A. caninum) is closely related to the human hookworm species $N$. americanus and $A$. duodenale. Phylogenetic studies highlight the close relationship between $A$. caninum, $N$. americanus and $A$. duodenale [54-58]. In addition, the life-cycles of A. caninum and $A$. duodenale are very similar [59]: both have a latent stage, faecal-oral transmission, larval hypobiosis and mammary-oral infection. The presence of a latent stage is important as these organisms have a predisposition to chemotherapeutic resistance [60] and are useful for the screening of anthelmintic drugs [61].

The dog hookworm has well-described physiology and biochemistry which situates it as a translational model The dog hookworm, A. caninum was described in 1859 by Ercolini, and its physiology, morphology, biology and epidemiology have been well described, making it a good candidate as a model for translational research. Initial studies focussed on the description, harvesting and optimisation of culture conditions for physiology experiments. It was determined that optimal conditions for harvested hookworms was a Krebs-Ringer solution with the addition of $50 \%$ dog serum, allowing adult worms to survive for up to 10 weeks [62]. These hookworms were able to reproduce and produce viable eggs. The addition of whole red blood cells did not have any effect on feeding activity and survival [62], and it was shown by other investigators that the majority of red blood cells pass through hookworms intact [63]. It was from these observations that it was assumed that hookworms get the majority of their nutrition from plasma rather than erythrocytes.

It is recognised that parasites convert their metabolic processes as they transition from free living to parasitic life-styles. However, little is known about the host cues and parasite molecular pathways which govern this process. Metabolic labelling studies in dog hookworm have determined that $C^{14}$-labelled glucose is not converted to glycogen [63], but is diverted into amino acid production [64] in a metabolism dominated by fermentative processes [65, 66]. Exposure of hookworm L3 to dog sera increases feeding rates [67], and large diffusible solutes (protein fraction) stimulate the consumption of glucose [62]. Cyanide inhibition studies show that the adult dog hookworm is capable of aerobic metabolism and has a tricarboxylic acid (TCA) cycle that is able to oxidize both pyruvic and succinic acids [68]. In addition, NADH respiration is not strongly coupled to oxidative phosphorylation, with evidence that hookworms lack respiratory control [69]. Adult A. caninum succinoxidase activity does not seem to be tightly coupled to the synthesis of ATP, and external NADH oxidation that is not coupled to phosphorylation can occur. The low ratios of phosphorylation/oxidation may reflect loosely coupled pathways of respiration or the existence of two pathways of respiration, one coupled to 
Table 1 The members of the Ancylostomatidae family and their hosts have overlapping distributions. Zoonotic disease potential, distribution and pathogenic significance are described in this table. Life-cycles A and B are described above

\begin{tabular}{|c|c|c|c|c|c|c|}
\hline Species & Definitive host & $\begin{array}{l}\text { Human } \\
\text { zoonosis }\end{array}$ & $\begin{array}{l}\text { Paratenic } \\
\text { host }\end{array}$ & $\begin{array}{l}\text { Global } \\
\text { incidence }\end{array}$ & Notes & Ref. \\
\hline $\begin{array}{l}\text { Ancylostoma } \\
\text { duodenale }\end{array}$ & Human & - & Cat, dog & $\begin{array}{l}\text { Europe, Africa, } \\
\text { India, China, } \\
\text { Asia, Americas }\end{array}$ & $\begin{array}{l}\text { Life-cycle A } \\
\text { as described } \\
\text { in [59]; } \\
\text { hypobiosis; } \\
\text { Wakana disease } \\
\text { in humans }\end{array}$ & [159-161] \\
\hline $\begin{array}{l}\text { Ancylostoma } \\
\text { caninum }\end{array}$ & Dog & $\begin{array}{l}\text { Cutaneous infection, } \\
\text { usually asymptomatic } \\
\text { and arrests in tissues; } \\
\text { adult worm in gut } \\
\text { can cause eosinophilic } \\
\text { enteritis }\end{array}$ & - & $\begin{array}{l}\text { Tropical and } \\
\text { subtropical } \\
\text { regions }\end{array}$ & $\begin{array}{l}\text { Life-cycle A; } \\
\text { hypobiosis }\end{array}$ & {$[86,162,163]$} \\
\hline $\begin{array}{l}\text { Ancylostoma } \\
\text { ceylanicum }\end{array}$ & $\begin{array}{l}\text { Dog, } \\
\text { cat, } \\
\text { human }\end{array}$ & - & Rodent & $\begin{array}{l}\text { Asia, India, } \\
\text { Sri Lanka, } \\
\text { Philippines, } \\
\text { Australia }\end{array}$ & Life-cycle A & {$[151,164-166]$} \\
\hline $\begin{array}{l}\text { Ancylostoma } \\
\text { braziliense }\end{array}$ & $\begin{array}{l}\text { Dog, } \\
\text { cat }\end{array}$ & $\begin{array}{l}\text { Cutaneous larva } \\
\text { migrans }\end{array}$ & Rodent & $\begin{array}{l}\text { Brazil, Africa, } \\
\text { India, } \\
\text { Sri Lanka, } \\
\text { Indonesia, } \\
\text { Philippines }\end{array}$ & Life-cycle A & {$[81,167]$} \\
\hline $\begin{array}{l}\text { Ancylostoma } \\
\text { pluridentatum }\end{array}$ & $\begin{array}{l}\text { Wild } \\
\text { cats, } \\
\text { jaguar, } \\
\text { leopard }\end{array}$ & None noted & - & $\begin{array}{l}\text { South and } \\
\text { Central Americas; } \\
\text { thought to be } \\
\text { introduced to } \\
\text { Florida bobcat } \\
\text { populations mid-1950s }\end{array}$ & Life-cycle A & {$[168,169]$} \\
\hline $\begin{array}{l}\text { Ancylostoma } \\
\text { tubaeforme }\end{array}$ & Cat, lynx & Cutaneous larva migrans & Rodent & Worldwide & Life-cycle A & {$[170,171]$} \\
\hline $\begin{array}{l}\text { Ancylostoma } \\
\text { kusimaense }\end{array}$ & Badger & None noted & Dog & Japan & Life-cycle A & [172] \\
\hline $\begin{array}{l}\text { Ancylostoma } \\
\text { protelesis }\end{array}$ & Aardwolf & Unknown & - & Africa & nd & {$[173]$} \\
\hline $\begin{array}{l}\text { Ancylostoma } \\
\text { somaliense }\end{array}$ & Jackal & Unknown & - & Africa & nd & [173] \\
\hline $\begin{array}{l}\text { Ancylostoma } \\
\text { genettae }\end{array}$ & $\begin{array}{l}\text { Genet } \\
\text { (small } \\
\text { African } \\
\text { carnivore) }\end{array}$ & Unknown & - & Africa & nd & [173] \\
\hline $\begin{array}{l}\text { Necator } \\
\text { americanus }\end{array}$ & $\begin{array}{l}\text { Human, } \\
\text { gorilla }\end{array}$ & Ground itch & - & $\begin{array}{l}\text { Africa, India, } \\
\text { Asia, China, } \\
\text { Central America }\end{array}$ & Life-cycle B & [174-176] \\
\hline $\begin{array}{l}\text { Necator } \\
\text { gorillae }\end{array}$ & Gorilla & Unknown & - & Africa & nd & {$[176]$} \\
\hline $\begin{array}{l}\text { Uncinaria } \\
\text { stenocephala }\end{array}$ & $\begin{array}{l}\text { Foxes, } \\
\text { wolves, } \\
\text { coyotes }\end{array}$ & $\begin{array}{l}\text { Cutaneous } \\
\text { larva migrans }\end{array}$ & $\begin{array}{l}\text { Dog, cat, } \\
\text { rodent }\end{array}$ & $\begin{array}{l}\text { Temperate } \\
\text { climates }\end{array}$ & Life-cycle B & {$[96,177]$} \\
\hline
\end{tabular}

Abbreviation: $n d$ life-cycle is not described in the literature

the esterification of inorganic phosphate and another to the NADH pathway [69].

Fatty acids produced by $A$. caninum are major end products of metabolism. Labelling studies have shown that glucose is metabolised to produce acetate, propionate and $\mathrm{CO}_{2}$ while the amino acids L-valine and L-leucine are the precursors of isobutyric acid and isovaleric acid, respectively [65]. Ancylostoma caninum adult worms consume larger quantities of oxygen than other intestinal nematodes [67]; however, they have been shown to fix $\mathrm{CO}_{2}$ to produce propionate from amino acids via a $\mathrm{CO}_{2}$ fixation pathway [65, 67]. Adult hookworms display a slowing or cessation of metabolic fermentation in the presence of oxygen [65], and the presence of oxygen inhibits anaerobic 
glycolysis. The interactions of the end products of hookworm metabolism with the host have never been explored. Similarly, there has been no investigation of the role of secondary metabolites produced by hookworms and their role in the host-parasite relationship.

Studies of hookworm transition through developmental stages have failed to comprehensively identify the triggers that control the penetration, migration and maturation in host tissues. Like the human hookworm A. duodenale [70], A. caninum in dog somatic tissues can enter hypobiosis, a hibernation-like state often compared to dauer formation in the free-living nematode Caenorhabditis elegans [71, 72]. Experimental infection of dogs with hookworms has increased our understanding of these processes. For example, experimental infection of dogs with $A$. caninum results in a greater proportion of parasites proceeding to hypobiosis in dogs which are immunosuppressed by corticosteroid treatment, and cessation of treatment results in resumption of parasite development, albeit in a relatively unpredictable manner [61]. The cause of this resumption is unknown but it implies complex molecular/physiological interactions between host and parasite through all stages of development.

The propensity to hypobiosis is a valuable characteristic of a model because hypobiotic larvae are less susceptible to anthelmintic drugs [60], presumably due to their ability to slow their metabolic processes. In vitro studies of $A$. caninum show recovery from hypobiosis can be induced by exposure to muscarinic acetylcholine receptor agonists and cyclic GMP. This activation process results in a rapid release of infection-associated proteins [71, 73, 74], which in part mimics the host-specific signalling events seen in L3 upon exposure to host serum [74]. Very little is known about the L3 lung stage of A. caninum or the triggers that prompt migration and maturation of the $\mathrm{L} 4$ as it arrives in the gastrointestinal tract and reaches sexual maturity in the small intestine. Recent reports show that $A$. caninum in older dogs induces a tolerogenic area around the site of attachment in the gut [75]. In addition, we know from proteomic and more targeted studies that A. caninum produces a number of proteins that putatively interact with immune cells and can induce anti-inflammatory responses [76-80] which in turn promotes tolerance in the host.

Our understanding of A. caninum as a human zoonosis has also changed over time. Initially the zoonosis was defined by larva migrans where the parasite could penetrate the epidermis but fails to successfully migrate and is trapped in the skin and underlying musculature, leading to localised irritation and pruritus [81-83]. It has now been shown that $A$. caninum is able to complete its migration in humans, with occasional worms reaching the human gut, although a patent human infection with $A$. caninum has yet to be reported. Studies in mice, a monkey and a cat have shown migration of the parasite into muscle tissues with little inflammatory response [84]. This phenomenon has also been reported in humans with migration of hookworms to muscle tissues in an individual with a large cutaneous exposure [85]. In 1994, Croese [86] described numerous cases where solitary A. caninum were identified in the human gut by endoscopy, discovered during clinical investigation for eosinophilic gastroenteritis [87]. These observations indicate that $A$. caninum could be a suitable proxy for human-hookworm interactions, and much can be learned about human hookworm infection by studying $A$. caninum in its natural dog host.

\section{Omics can provide useful information but must be augmented with information from animal models}

Omics is the collective term for the characterisation of an organism at the genome, transcriptome, proteome and metabolome levels. Increasingly, omics have been used to guide research in host-parasite biology and therapeutics discovery. This approach has been used in the case of parasitic trematodes to identify the mechanisms of drug resistance and to identify novel drug targets [88]. Metagenomics and metabolomics are the newest and most rapidly advancing 'omics' technologies, and offer under-utilised promise for understanding the molecular basis of host-helminth interactions, particularly metabolism, pharmacotherapeutic action [89] and the presence and function of commensal microbes. The limitation of comparative omics is that often there are no homologs or orthologs of helminth molecules (particularly proteins) in other organisms to assign putative function, and many of the metabolites are of unknown origin and function. For example, there are over 700 transcripts in the $A$. caninum transcriptome encoding for proteins with secretory signal peptides with no function assigned [90]. Unannotated genes in parasites are of interest due to their likely role in governing a parasitic existence [91]. To augment omics databases to allow for meaningful bioinformatics analyses, animal models provide invaluable information. These models provide important bioactivity information that cannot be inferred by bioinformatics alone [39].

We have assembled the currently available omics information for the family Ancylostomatidae in Table 2, and have included for comparison the free-living model nematode C. elegans and the filarial nematode Brugia malayi. By using comparative tools it was possible using these databases to identify genes putatively associated with parasitism by comparing the different transcriptome patterns of the three helminth species [90]. Mining of assembled proteomic databases can help to identify proteins, but often the target protein is of unknown. For 
Table 2 The current omics status for the Ancylostomatidae, the free-living model nematode Caenorhabditis elegans, and the filarial nematode Brugia malayi. Genome and transcriptome progress for Ancylostomatidae can be monitored on the Gold-genome online database (https://gold.jgi.doe.gov/distributiondata?domain=EUKARYAL\&rank=family\&group=Ancylostomatidae.). Transcriptome, proteome and metabolome database updates can also be monitored on (http://www.genome.jp/kegg/kegg1.html) and Wormbase; (www.wormbase.org)

\begin{tabular}{llllll}
\hline Organism & Genome & Transcriptome & $\begin{array}{l}\text { Proteome/ } \\
\text { secretome }\end{array}$ & Metabolome & Reference \\
\hline C. elegans & $\times$ & $\times$ & $\times$ & $\times$ & {$[178-187]$} \\
N. americanus & $\times$ & $\times$ & $\times$ & - & - \\
A. duodenale & - & - & - & - & - \\
A. caninum & $\times$ & $\times$ & $\times$ & - & {$[76,130,132,188-192]$} \\
A. ceylanicum & $\times$ & $\times$ & - & - & {$[193,196]$} \\
A. braziliense & - & $\times$ & $\times$ & {$[197]$} \\
Brugia malayi & $\times$ & $\times$ & & {$[9,90,198-203]$} \\
\hline
\end{tabular}

${ }^{a}$ Data collection still in process

Key: $\times$, omics data available; - , omics data not available

example, using a shotgun proteomics approach Mulvenna et al. [76] identified $105 \mathrm{~A}$. caninum ES proteins increased recently to 315 putative proteins in our laboratory [92]. Based on gene ontology alone many of these are putative or of unknown function [76, 92].

Current databases for helminth omics, particularly hookworm, are incomplete. Only $N$. americanus has a published genome [93], and only A. caninum has a comprehensive secreted proteome from the adult worm [76], although the somatic adult worm proteome has been reported from $N$. americanus [93]. The plasticity and adaptability of hookworms further accentuates the deficit in bioinformatics data. Significant subpopulation variation of A. caninum has been observed [94], and it has been speculated that this variation may indicate speciation events. In addition, these subpopulations could reflect differences in infectivity for $A$. caninum [95]. The analysis of restriction fragment length polymorphisms (RFLP) of helminths from India and Vietnam supports the observed phylogenetic relationships but also identifies unclassified Ancylostoma species [96, 97]. This pattern is also observed with $N$. americanus $[98,99]$. The source of hookworm material used to generate different omics databases is usually restricted to small populations, often passaged through unnatural hosts, and different populations are frequently used to compile different datasets (see Table 2). In conjunction with the known plasticity of hookworm species, these factors may diminish valid comparisons across databases. By using in silico techniques it is possible to use comparative bioinformatics to combine proteomic and transcriptomic databases to determine metabolic pathways [100].

Combining omics data with functional data from animal models is a very powerful tool to identify critical physiologic and metabolic pathways. Helminth genomes are often poorly annotated, which can result in missed identifications of novel pathways in parasites. For example, it is only from metabolic labelling of metabolic intermediates of the Leishmania parasite promastigotes that it was possible to show that the parasite pooled reservoirs of essential molecules for the TCA cycle through the fermentation of succinate [28]. This is a novel pathway that could potentially be used as a target for antiparasitic drugs and provides an understanding of how parasites cope with changes in their environment. The metabolome of Entamoeba during encystation shows the presence of polyamines [101], an unexpected finding given that the enzymes responsible for polyamine biosynthesis are not annotated in the genome [102]. Eicosanoids in helminths are likely produced by novel pathways, as bioinformatics searches for the genes encoding homologues of the mammalian enzymes in this biosynthesis pathway have not been identified [103]. Given these examples, and the adaptability of the hookworm and its phenotypic plasticity, metabolomics profiling is likely necessary to uncover novel pathways and molecules used by these parasites [104].

\section{Animal models of hookworm interaction}

One of the major issues with the study of hookworms is the inability to culture these parasites through all developmental stages of their life-cycle in vitro. To this end, animal models are employed. The ideal model for human hookworm infection should reflect the pathophysiology of the helminth-host interaction and be experimentally accessible. Current models all have limitations and many animal experiments are considered "under-powered" [105] due to the ethical restrictions on animal experimentation numbers. A further restriction on models is the availability of immunological reagents for particular species. Reagents are readily available for humans, mice/rats, and to a lesser extent dogs and hamsters, but are more restricted for cats, which only have a limited palette of immune reagents. 
Moreover, human hookworms do not generally reach maturity in mice or rats [106, 107], precluding functional studies using genetically modified hosts.

There are three main experimental animal models commonly used as a proxy for gastrointestinal (GI) nematode infections of humans; mice/rat, hamsters and dogs as summarised in Table 3. There have been attempts to establish hookworm-primate models using marmots [108] however these models have been constricted by experimental cost [109]. The two benchmark murine models used for STH infection discussed in this review are Heligmosomoides polygyrus bakeri and Nippostrongylus brasiliensis. Trichuris muris is homologous to the human whipworm Trichuris trichiura, and while it is a STH it is not within the scope of this review. The rat is the natural host of $N$. brasiliensis and is considered a good model for human hookworm infection, particularly due to the similarities between the $N$. brasiliensis and $N$. americanus secretomes [110]. However, there are some features of the $N$. brasiliensis life-cycle in rodents that are dissimilar to human hookworm infections, particularly the rapid transit time from percutaneous infection to reaching the gut, as noted below. Nippostrongylus brasiliensis is not a natural parasite of mice, although it can complete its life-cycle in them.
While $N$. brasiliensis is less closely related phylogenetically to human hookworms than are other Ancylostoma spp., it is often used to study the pathophysiology and immunology of STH infection. One of the major differences between human hookworm infection and $N$. brasiliensis infection in mice is the self-cure phenomenon that occurs. Within two weeks of infection, mice expel the parasite and develop protective immunity that is dependent on $\mathrm{CD} 4{ }^{+} \mathrm{Th} 2$ cells. Indeed, this model has been used to study the development of host protective immunity and the in vivo regulation of Th2 responses in general [111-113]. One of the advantages of this model is the minimal interanimal variation, however, its life-cycle is abbreviated and is not characterised by the chronicity of human hookworm infection.

As a natural parasite of mice, $H$. polygyrus is often chosen to study the pathophysiology and the immunology of intestinal nematode infections [111, 114, 115]. While taxonomically related to human hookworms, $H$. polygyrus differs from human hookworms in that it has a much simpler life-cycle. Heligmosomoides polygyrus does not have a lung stage and exhibits an enteric lifecycle with a faecal-oral infection route. However, like human hookworm infection, $H$. polygyrus establishes a chronic infection in its definitive host. As such, this

Table 3 The major animal models used to study human hookworm infection

\begin{tabular}{|c|c|c|c|c|c|c|}
\hline Animal model & $\begin{array}{l}\text { Naturally } \\
\text { occurring } \\
\text { host-parasite }\end{array}$ & $\begin{array}{l}\text { Similar life-cycle } \\
\text { cf. Necator/ } \\
\text { Ancylostoma } \\
\text { spp. in humans }\end{array}$ & $\begin{array}{l}\text { Infection } \\
\text { model }\end{array}$ & $\begin{array}{l}\text { Model used } \\
\text { to study }\end{array}$ & $\begin{array}{l}\text { Regulatory } \\
\text { restrictions }\end{array}$ & Reference \\
\hline \multicolumn{7}{|l|}{ Mouse (Mus musculus) } \\
\hline $\begin{array}{l}\text { Heligmosomoides } \\
\text { polygyrus bakeri }\end{array}$ & Yes & $\begin{array}{l}\text { No (no lung } \\
\text { stage) }\end{array}$ & $\begin{array}{l}\text { Chronic } \\
\text { helminthiasis }\end{array}$ & $\begin{array}{l}\text { Pathophysiology of } \\
\text { infection, immunological } \\
\text { studies, vaccinomics }\end{array}$ & - & {$[114,115,204-208]$} \\
\hline $\begin{array}{l}\text { Nippostrongylus } \\
\text { brasiliensis }\end{array}$ & No & Yes & $\begin{array}{l}\text { Rapid } \\
\text { expulsion }\end{array}$ & $\begin{array}{l}\text { Immunology of } \\
\text { helminth infection, } \\
\text { pathophysiology } \\
\text { of infection }\end{array}$ & - & {$[110,207,209-212]$} \\
\hline \multicolumn{7}{|l|}{$\begin{array}{l}\text { Golden Syrian } \\
\text { hamster (M. auratus) }\end{array}$} \\
\hline $\begin{array}{l}\text { Ancylostoma } \\
\text { ceylanicum }\end{array}$ & No & $\begin{array}{l}\text { No (infection } \\
\text { by oral gavage) }\end{array}$ & $\begin{array}{l}\text { Rapid } \\
\text { expulsion }\end{array}$ & $\begin{array}{l}\text { Vaccinomics, } \\
\text { anti-helminthics }\end{array}$ & $\begin{array}{l}\text { Hamsters not } \\
\text { permitted in } \\
\text { some countries } \\
\text { (e.g. Australia) }\end{array}$ & {$[123,213,214]$} \\
\hline Necator americanus & No & Yes & $\begin{array}{l}\text { Chronic } \\
\text { helminthiasis }\end{array}$ & $\begin{array}{l}\text { Pathophysiology } \\
\text { of infection, } \\
\text { immunological } \\
\text { studies, vaccinomics }\end{array}$ & $\begin{array}{l}\text { Hamsters not } \\
\text { permitted in } \\
\text { some countries. } \\
\text { Ova transport } \\
\text { restricted in US }\end{array}$ & {$[121,215,216]$} \\
\hline \multicolumn{7}{|l|}{$\begin{array}{l}\text { Beagle }{ }^{a} \text { (Canis } \\
\text { lupus familiaris) }\end{array}$} \\
\hline $\begin{array}{l}\text { Ancylostoma } \\
\text { caninum }\end{array}$ & Yes & $\begin{array}{l}\text { Yes including } \\
\text { hypobiosis }\end{array}$ & $\begin{array}{l}\text { Acute and } \\
\text { chronic } \\
\text { helminthiasis }\end{array}$ & $\begin{array}{l}\text { Pathophysiology } \\
\text { of infection, } \\
\text { immunological } \\
\text { studies, vaccinomics }\end{array}$ & Ethical considerations & [144] \\
\hline
\end{tabular}


model has been used to extensively characterise the Th2-skewing and immunoregulatory properties of GI nematodes [116], and ultimately resulted in the introduction of the term "modified Th2 response" [117].

The mouse models of $N$. brasiliensis and $H$. polygyrus have been used to decipher the innate and adaptive immune responses responsible for worm expulsion and the development of chronicity [118]. Both parasites drive a modified Th2 response typified by IL-4, IL-5, IL-9, IL-13 and IL-10 which mediates eosinophilia, mucosal changes such as mast cell hyperplasia, mucus production and IgG1 and IgE production [119].

One of the most important breakthroughs in the development of animal models for human hookworm infection was the establishment of patent infections in golden Syrian hamsters (Mesocricetus auratus) with $N$. americanus and $A$. ceylanicum. Both models however are "labours of love" and require considerable time to establish because they generally rely on immunosuppression with steroids, at least in the early phases of model establishment [120-122]. Immunosuppression with steroids of the golden Syrian hamster allows A. ceylanicum and $N$. americanus infections to reach patency [121, 123], thereby providing material for laboratory analyses including genomic, transcriptomic and metabolomics studies. The A. ceylanicum-hamster model [124] has been utilized for testing vaccine efficacy, understanding mechanisms of adaptive immunity, and testing of anthelminthic drugs, often as a model for human infection with $N$. americanus [106, 125]. These interpretations have been supported by observations in small scale studies in humans [126-128].

The $N$. americanus-hamster model was first established by Sen \& Seth in 1970 [129], and tailored as a model for testing drugs and vaccines by Jian et al. in 2003 [121]. Importantly, the in vivo generation of adultstage $N$. americanus enabled the sequencing of the adult worm transcriptome [130], and ultimately contributed material to the sequencing of the genome in 2014 [93]. It should be noted that $N$. americanus was adapted to hamsters through 100 generations of selective pressure. The ability of a complex multicellular pathogen to adapt to a new host within 100 generations reflects a high evolutionary rate also observed in A. caninum and reflected by high DNA polymorphism [90]. We currently do not understand the molecular basis of the adaptation of $N$. americanus to the golden hamster. A comparative analysis of mitochondrial cytochrome oxidase from $N$. americanus obtained from hamsters and natural human infections suggests a severe genetic bottleneck in hamster-adapted $N$. americanus which may limit the utility of this model [131]. To date, there has been no investigation of the differences in genomes between $N$. americanus sourced from hamsters and those from the native human host. The 'omics' information garnered from such a comparison would be useful to highlight those genes related to host adaption and could also enhance our understanding of the metabolites produced by a system in response to changes in the host and an environmental stimulus.

There are a number of caveats to consider in the hamster model of human hookworm infection. Interpretation of data generated in the $N$. americanus-adapted hamster model may be misleading when applied to human hookworm host-parasite biology due to the undefined changes discussed above. In addition, the model using immunosuppressed hamsters and $N$. americanus is still employed [132, 133], so care should be taken when interpreting results and drawing parallels between the two models. Another problem with the hamster model of $N$. americanus infection is its restricted geographic use; for example, hamsters are a prohibited laboratory species in Australia due to strict quarantine restrictions [134]. This limits its ability to be used in comparative and translatable studies universally. Logistically, the hamster is a small animal so the parasite load that the animal can tolerate is low when compared to a human or larger animal such as a dog. Moreover, adult N. americanus do not reach full size in hamsters [121], even though they do become fecund and infections are patent. A further weakness of this model is that the small numbers of adult parasites that can be supported in hamsters are rapidly expelled compared to the chronicity that develops in human infection [135].

\section{The canine-hookworm model}

The gut-dwelling, blood-feeding stage of $A$. caninum is well described at biochemical, transcriptomic and immunological levels as discussed here. The excretory/ secretory (ES) component of A. caninum (AcES) at the host-parasite interface has been described, with over 100 proteins identified in 2009 [76], many of which were ascribed to either feeding [136-138] or putatively evading the host and inducing tolerance [75, 78]. The immunomodulatory nature of AcES has been demonstrated [77, 139] with an increasing interest in translational applications for components from AcES [80, 136, 140-142]. In addition, possible mechanisms of resistance [15] and hypobiosis [84] have been studied in this model. The availability of such an accessible and defined model is attractive for a gamut of research agendas.

A major advantage of the A. caninum-dog relationship as a model for human hookworm infection is that it is naturally occurring, and moreover, A. caninum and $A$. duodenale are very similar morphologically and genetically. Due to the larger size of the animal, dogs are more suitable for recovering larger quantities of adult hookworms for laboratory studies. From an individual dog it 
may be possible to recover thousands of adult worms, allowing for comprehensive studies to occur from a single collection. One of the major objections to the use of dogs as animal models however is the ethical concern around their experimental use; this, combined with the expense of keeping such a large animal for research purposes, often limits the use of the $A$. caninum-canine model. Attempts have been made to create an A. duodenale-dog model for research purposes. Using immunosuppression with prednisolone it was possible to achieve patency within six generations of beagle [143]. In later experiments $A$. duodenale was maintained in laboratoryraised beagles for 30 generations using decreasing amounts of prednisolone, and adaption to the dog was presumed due to observed decreases in the prepatent period for the parasite, however a fully permissive model was not achieved due to the prohibitive resource demands of the project [144]. This is a common theme with large animal models.

Puppies usually harbour the heaviest burdens of $A$. caninum, and worm numbers (or at least eggs in the faeces) tend to diminish over time. An efficacious hookworm vaccine based on irradiated parasites was developed for dogs but was discontinued soon after reaching the market due to its poor shelf life and low uptake by pet owners $[145,146]$. The dog hookworm vaccine was based on radiation-attenuated L3 [146], and although the protective antigenic components were not identified, two immunodominant L3 secreted antigens were described from dogs that received the vaccine [147]. Understanding the mechanisms by which vaccineinduced immunity to the dog hookworm develops could inform efforts to develop a subunit human hookworm vaccine. Such studies have guided antigen discovery for human hookworm vaccines [148], and even underpin proposed human trials with irradiated $N$. americanus L3 (AL, unpublished).

It is our experience that the dog-hookworm model can be very fruitful when $A$. caninum is sourced from areas where dogs are naturally infected, have not received recent anthelmintic therapy, and dogs are excess to requirements. These unwanted animals can result from wild dog eradication programmes, the culling of rural/ remote camp or village dogs, or the sourcing of stray or unwanted dogs from residential communities in tropical and sub-tropical environments. The benefit of this approach is three-fold: (i) ethically, these animals are not experimentally infected or euthanized for research purposes, so ethical concerns on their use are minimised; (ii) international partnerships between developed and developing countries to source these hookworms means that educational/research facilities can be meaningfully engaged in STH research; and (iii) harvesting of animals from diverse geographical areas gives power to observations as it reflects natural host-parasite interactions and natural spatio-temporal variation.

The opportunity for international partnering is emphasised in the modern research agenda as it aids capacity building in developing countries [149] that are most affected by STH. It enables the development of collaborative long-term partnerships and stewardship over research agendas. This is particularly important in the case of human hookworm research as there are direct benefits to both developed and developing nations in terms of vaccine and drug development [150], as well as development of novel helminth-derived antiinflammatory therapeutics [80]. Additionally, partnering provides the ability to extend research capabilities in a time of increasing economic rationalisation and competitive grant processes. The inclusion of a broad base of expertise from immunology, parasitology, veterinary and agricultural sciences, public health and medicine is possible in these partnerships and is often aligned with current integrated approaches to research programs.

\section{Ancylostoma ceylanicum as a model for human hookworms}

Ancylostoma ceylanicum is one of the most indiscriminate hookworms, with the ability to naturally infect dogs, cats, humans and other animals. It is a dominant hookworm in Asia and present throughout Australasia [151, 152], and a permissive model in hamsters is available. To date, models utilising hamsters and mice infected with A. ceylanicum have been used to study pathogenesis [123]. This hookworm has the potential to be valuable in comparative 'omics' studies. For example, using transcriptomics approaches, putative anthelmintic drug targets were identified [153]. Comparing the transcriptomes of adult $A$. ceylanicum hookworms isolated from feline, canine and other animal infections has the potential to identify molecules that are responsible for the promiscuity in host preference for this parasite. Like in A. caninum infection, dogs infected with A. ceylanicum develop functional immunity to the parasite [154]. The advantage of $A$. ceylanicum as a model parasite is that it regularly reaches patency in both humans and dogs $[151,155]$.

Ancylostoma ceylanicum is closely related to both $A$. duodenale and A. caninum $[55,156]$, so the molecular mechanisms by which they regulate and skew the host's immune pathways are likely to be shared between species. However, observations of other parasites show there are a wide number of adaptions to the parasitic life-style [157]. For example, there are classes of parasite proteins that have been implicated in host-parasite interactions with many having pleiotropic actions [39, 157, 158]. A comparative study of $A$. ceylanicum, A. caninum and $A$. 
duodenale may reveal unique adaptions for each of these closely related species.

Phenotypically, A. ceylanicum and A. brasiliensis can be easily confused, making it necessary to augment collection of parasites from natural infections with molecular characterisation $[96,151]$. This complicates acquiring hookworms from naturally infected dogs where the distribution of these hookworms overlaps. The secretome has yet to be defined at the protein level for N. americanus, A. duodenale or A. ceylanicum, limiting the ability to make confident assumptions about sequence conservation of secreted proteins between these species. It is for these reasons that $A$. ceylanicum is a more limited model hookworm.

\section{Conclusions}

In the context of human hookworm research, the human-hookworm-dog axis provides one of the most unique experimental opportunities for the identification of bioactive molecules for development of novel immunotherapeutics, subunit vaccines, and selection of drug targets. Domestication has meant that the unique evolutionary relationships between dogs and humans can be exploited as natural models for human diseases, notably from our perspective, the parasitic helminth infections of humans. Positive selection pressure and breed conformation has led to genetic restriction in canines, and has meant that many diseases have the same underlying genetic basis in dogs and humans. It is likely that humans and dogs have shared parasites for millennia, making them an ideal model for the study of hostparasite biology. Laboratory evidence shows that with the administration of immunosuppressive therapy it is possible to achieve patency of hookworm infections in a variety of unnatural definitive hosts. There are a number of available models for human hookworm infection; however, all of these models have limitations. Mouse models are universally available yet suffer from a range of dissimilarities to the natural human hookworm infections. Hamster models have an advantage over mouse models in that they are permissive for the human hookworms $N$. americanus and A. ceylanicum, but resistance to infection develops rapidly, unlike human hookworm infections. Ancylostoma caninum in the dog is a robust, naturally occurring relationship, and parasites isolated from animals in endemic areas have the potential to provide powerful molecular information that is unavailable from other sources, and reflects naturally occurring interactions. The use of experimentally infected large animal models for such studies is fraught with ethical considerations and high economic costs. The study of natural interactions has the potential to provide more powerful observations than those of current laboratory models. Sourcing naturally infected animals provides an opportunity for international partnering and an opportunity for a diverse portfolio of translatable research outcomes. It negates many of the ethical and cost concerns rightly expressed over the housing of large mammals. By using a strong model for sourcing parasite material it is possible to make reliable and translatable observations about hookworm host-parasite biology as well as facilitating programs focused on development of new control strategies aimed at eliminating, or at least mitigating, hookworm infection.

\section{Abbreviations \\ AcES: A. caninum ES component; ATP: Adenosine triphosphate; CGMP: Cyclic guanosine monophosphate; $\mathrm{CO}_{2}$ : Carbon dioxide; DCM: Dilated cardiomyopathy; DNA: Deoxyribonucleic acid; ES: Excretory/secretory; IBD: Inflammatory bowel disease; MCH: Major histocompatibility complex; NADH: Nicotinamide adenine dinucleotide; RFLP: Restriction fragment length polymorphisms; SLE: Systemic lupus erythematous; SNPs: Single nucleotide polymorphisms; STH: Soil-transmitted helminths; \\ TCA: Tricarboxylic acid}

\section{Acknowledgements}

With thanks to Dr Patricia Graves, Adjunct Professor, College of Public Health, Medical and Vet Sciences, James Cook University, Australia for manuscript review and advice.

\section{Funding}

This work was supported by a National Health and Medical Research Council (NHMRC) program grant (APP1037304) and senior principal research fellowship (APP1132975) to AL. PW was supported by a NHMRC Peter Doherty Early Career Researcher fellowship (APP1091011). CS was supported by an Australian Postgraduate Award from James Cook University. The funders had no role in design, decision to publish, or preparation of the manuscript.

\section{Availability of data and materials}

Not applicable.

\section{Authors' contributions}

CS conceived and wrote the manuscript. PW assisted with the concept and contributed to the manuscript. AL contributed to design of review, interpretation of data and contributed to authorship of the review. All authors read and approved the final manuscript.

Ethics approval and concent to participate

Not applicable.

Consent for publication

Not applicable.

Competing interests

The authors declare that they have no competing interests.

\section{Publisher's Note}

Springer Nature remains neutral with regard to jurisdictional claims in published maps and institutional affiliations.

Received: 27 September 2017 Accepted: 3 January 2018

Published online: 25 January 2018

\section{References}

1. Bethony J, Brooker S, Albonico M, Geiger SM, Loukas A, Diemert D, et al. Soil-transmitted helminth infections: ascariasis, trichuriasis, and hookworm. Lancet. 2006;367:1521-32.

2. The World Health Report. Making a difference. Geneva: World Health Organization; 1999. p. 1999. 
3. Hotez PJ, Bethony J, Bottazzi ME, Brooker S, Diemert D, Loukas A. New technologies for the control of human hookworm infection. Trends Parasitol. 2006;22:327-31.

4. Hotez PJ, Brindley PJ, Bethony JM, King CH, Pearce EJ, Jacobson J. Helminth infections: the great neglected tropical diseases. J Clin Invest. 2008;118: 1311-21.

5. Soil-transmitted helminth infections. World Health Organisation; 2017. http://www.who.int/mediacentre/factsheets/fs366/en/.

6. Elman C, McGuire RA, Wittman B. Extending public health: the Rockefeller Sanitary Commission and hookworm in the American South. Am J Public Health. 2014;104:47-58

7. Fenwick A, Webster JP, Bosque-Oliva E, Blair L, Fleming FM, Zhang Y, et al. The Schistosomiasis Control Initiative (SCI): rationale, development and implementation from 2002-2008. Parasitology. 2009;136:1719-30.

8. Crompton D. World Health Organization: Preventive chemotherapy in human helminthiasis: Coordinated use of anthelminthic drugs in control interventions: a manual for health professionals and programme managers. World Health Organisation: Geneva; 2006.

9. Ballesteros C, Tritten L, O'Neill M, Burkman E, Zaky WI, Xia J, et al. The effect of in vitro cultivation on the transcriptome of adult Brugia malayi. PLoS Negl Trop Dis. 2016;10(1):e0004311.

10. Geary TG, Sakanari JA, Caffrey CR. Anthelmintic drug discovery: Into the future. J Parasitol. 2015;101:125-33.

11. Wang $W$, Wang $L$, Liang $Y S$. Susceptibility or resistance of praziquantel in human schistosomiasis: a review. Parasitol Res. 2012;111:1871-7.

12. Geerts $S$, Gryseels B. Drug resistance in human helminths: Current situation and lessons from livestock. Clin Microbiol Rev. 2000;13:207-22.

13. Prichard RK. Markers for benzimidazole resistance in human parasitic nematodes? Parasitology. 2007;134(Special Issue 08):1087-92.

14. Martin RJ, Robertson AP. Mode of action of levamisole and pyrantel anthelmintic resistance, E153 and Q57. Parasitology. 2007;134:1093-104.

15. Kopp SR, Coleman GT, Traub RJ, McCarthy JS, Kotze AC. Acetylcholine receptor subunit genes from Ancylostoma caninum: altered transcription patterns associated with pyrantel resistance. Int J Parasitol. 2009;39:435-41.

16. Shalaby HA. Anthelmintics resistance; how to overcome it? Iran J Parasitol. 2013:8:18-32.

17. Kohler $P$. The biochemical basis of anthelmintic action and resistance. Int Parasitol. 2001:31:336-45

18. Reynoldson JA, Behnke JM, Pallant LJ, Macnish MG, Gilbert F, Giles S, et al. Failure of pyrantel in treatment of human hookworm infections (Ancylostoma duodenale) in the Kimberley region of North West Australia. Acta Trop. 1997;68:301-12.

19. Kaplan RM. Drug resistance in nematodes of veterinary importance: a status report. Trends Parasitol. 2004;20:477-81.

20. Rose H, Rinaldi L, Bosco A, Mavrot F, de Waal T, Skuce P, et al. Widespread anthelmintic resistance in European farmed ruminants: a systematic review. Vet Rec. 2015;176(21):546.

21. Cotter $\mathrm{J}$, Van Burgel A, Besier RB. Anthelmintic resistance in nematodes of beef cattle in south-west Western Australia. Vet Parasitol. 2015;207:276-84.

22. Vercruysse J, Levecke B, Prichard R. Human soil-transmitted helminths: implications of mass drug administration. Curr Opin Infect Dis. 2012; 25:703-8.

23. Sangster NC. Anthelmintic resistance: past, present and future. Int J Parasitol. 1999:29:115-24

24. Prichard R. Anthelmintic resistance. Vet Parasitol. 1994;54:259-68.

25. Burns AR, Luciani GM, Musso G, Bagg R, Yeo M, Zhang $Y$, et al. Caenorhabditis elegans is a useful model for anthelmintic discovery. Nat Commun. 2015;6:7485.

26. Wolstenholme AJ, Martin RJ. Anthelmintics - from discovery to resistance. Int J Parasitol Drugs Drug Resist. 2014;4:218-9.

27. Hotez PJ, Ghosh K, Hawdon JM, Narasimhan S, Jones B, Shuhua X, et al. Experimental approaches to the development of a recombinant hookworm vaccine. Immunol Rev. 1999:171:163-71.

28. Saunders EC, de Souza DP, Chambers JM, Ng M, Pyke J, McConville MJ. Use of (13)C stable isotope labelling for pathway and metabolic flux analysis in Leishmania parasites. Meth. Mol Biol. 2015;1201:281-96.

29. Pearson MS, Jariwala AR, Abbenante G, Plieskatt J, Wilson D, Bottazzi ME, et al. New tools for NTD vaccines: A case study of quality control assays for product development of the human hookworm vaccine Na-APR-1M74. Hum Vacc Immunotherap. 2015;11:1251-7.
30. Diemert DJ, Bethony JM, Hotez PJ. Hookworm vaccines. Clin Infect Dis. 2008;46:282-8.

31. Rook GA. Hygiene hypothesis and autoimmune diseases. Clin Rev Allergy Immunol. 2012:42:5-15.

32. Flohr C, Tuyen LN, Lewis S, Quinnell R, Minh TT, Liem HT, et al. Poor sanitation and helminth infection protect against skin sensitization in Vietnamese children: A cross-sectional study. J Allergy Clin Immunol. 2006;118:1305-11.

33. Prideaux L, Kamm MA, De Cruz PP, Chan FK, Ng SC. Inflammatory bowel disease in Asia: a systematic review. J Gastroenterol Hepatol. 2012;27:1266-80.

34. Chacin-Bonilla L. Relevance of helminths in the prevention and healing of immune diseases. Investig Clin. 2009;50:1-4.

35. Okada H, Kuhn C, Feillet H, Bach JF. The 'hygiene hypothesis' for autoimmune and allergic diseases: an update. Clin Exp Immunol. 2010;160:1-9.

36. Elliott DE, Summers RW, Weinstock JV. Helminths and the modulation of mucosal inflammation. Curr Opin Gastroenterol. 2005:21:51-8.

37. Fleming JO. Helminth therapy and multiple sclerosis. Int J Parasitol. 2013;43:259-74

38. Weinstock JV, Elliott DE. Translatability of helminth therapy in inflammatory bowel diseases. Int J Parasitol. 2013:43:245-51.

39. Shepherd C, Navarro S, Wangchuk P, Wilson D, Daly NL, Loukas A. Identifying the immunomodulatory components of helminths. Parasite Immunol. 2015;37:293-303.

40. Navarro S, Ferreira I, Loukas A. The hookworm pharmacopoeia for inflammatory diseases. Int J Parasitol. 2013:43:225-31.

41. Wang G-D, Zhai W, Yang H-C, Wang L, Zhong L, Liu Y-H, et al. Out of southern East Asia: the natural history of domestic dogs across the world. Cell Res. 2016;26:21-33.

42. Boyko AR. The domestic dog: man's best friend in the genomic era. Genome Biol. 2011;12(2):1-10.

43. Lindblad-Toh K, Wade CM, Mikkelsen TS, Karlsson EK, Jaffe DB, Kamal M, et al. Genome sequence, comparative analysis and haplotype structure of the domestic dog. Nature. 2005:438:803-19.

44. Wang G-D, Zhai W, Yang H-C, Fan R-X, Cao X, Zhong L, et al. The genomics of selection in dogs and the parallel evolution between dogs and humans. Nat Commun. 2013;4:1860

45. Ostrander EA, Wayne RK. The canine genome. Genome Res. 2005; 15:1706-16.

46. Axelsson E, Ratnakumar A, Arendt M-L, Maqbool K, Webster MT, Perloski $M$, et al. The genomic signature of dog domestication reveals adaptation to a starch-rich diet. Nature. 2013:495:360-4.

47. Song SJ, Lauber C, Costello EK, Lozupone CA, Humphrey G, Berg-Lyons $D$, et al. Cohabiting family members share microbiota with one another and with their dogs. elife. 2013;2:e00458.

48. Parker HG, Shearin AL, Ostrander EA. Man's best friend becomes biology's best in show: Genome analyses in the domestic dog. Annu Rev Genet. 2010;44:309-36.

49. Silva LM E, Miranda RR, Santos HA, Rabelo EM. Differential diagnosis of dog hookworms based on PCR-RFLP from the ITS region of their rdna. Vet Parasitol. 2006:140:373-7.

50. Traub RJ, Hobbs RP, Adams PJ, Behnke JM, Harris PD, Thompson RCA A case of mistaken identity - reappraisal of the species of canid and felid hookworms (Ancylostoma) present in Australia and India. Parasitology. 2007;134:113-9.

51. Araujo A, Reinhard KJ, Ferreira LF, Gardner SL. Parasites as probes for prehistoric human migrations? Trends Parasitol. 2008:24:112-5.

52. Araujo A, Reinhard K, Ferreira LF, Pucu E, Chieffi PP. Paleoparasitology: the origin of human parasites. Arq Neuropsiquiatr. 2013;71:722-6.

53. Goncalves ML, Araujo A, Ferreira LF. Human intestinal parasites in the past: new findings and a review. Mem Inst Oswaldo Cruz. 2003; 98(Suppl. 1):103-18.

54. Hu M, Chilton NB, Gasser RB. The mitochondrial genomes of the human hookworms, Ancylostoma duodenale and Necator americanus (Nematoda: Secernentea). Int J Parasitol. 2002;32:145-58.

55. Chilton NB, Gasser RB. Sequence differences in the internal transcribed spacers of DNA among four species of hookworm (Ancylostomatoidea: Ancylostoma). Int J Parasitol. 1999:29:1971-7.

56. Cantacessi C, Hofmann A, Pickering D, Navarro S, Mitreva M, Loukas A. Timps of parasitic helminths - a large-scale analysis of high-throughput sequence datasets. Parasit Vectors. 2013;6:156

57. Blaxter M. Genes and genomes of Necator americanus and related hookworms. Int J Parasitol. 2000;30(4):347-55. 
58. Catalano S, Lejeune M, van Paridon B, Pagan CA, Wasmuth JD, Tizzani P, et al. Morphological variability and molecular identification of Uncinaria spp. (Nematoda: Ancylostomatidae) from grizzly and black bears: new species or phenotypic plasticity? J Parasitol. 2015;101:182-92

59. Hotez PJ, Brooker S, Bethony JM, Bottazzi ME, Loukas A, Xiao S. Hookworm infection. New Eng J Med. 2004;351:799-807.

60. Anderson RM. Epidemiology of parasitic infections. In: Wilson T, editor. Topley and Wilson's microbiology and microbial infections. New York: John Wiley \& Sons, Ltd; 2010.

61. Schad GA, Page MR. Ancylostoma caninum: adult worm removal, corticosteroid treatment, and resumed development of arrested larvae in dogs. Exp Parasitol. 1982;54:303-9.

62. Komiya Y, Yasuraoka K, Sato A. Survival of Ancylostoma caninum in vitro. I. Jpn J Med Sci Biol. 1956;9:283-92.

63. Fernando MA, Wong HA. Metabolism of hookworms. II. Glucose metabolism and glycogen synthesis in adult female Ancylostoma caninum. Exp Parasitol. 1964:15:284-92

64. Perez Gimenez ME, Gimenez A, Gaede K. Metabolic transformation of 14C-glucose into tissue proteins of Ancylostoma caninum. Exp Parasitol. 1967;21:215-23

65. Warren LG, Poole WJ. Biochemistry of the dog hookworm. II. Nature and origin of the excreted fatty acids. Exp Parasitol. 1970;27:408-16.

66. Müller M, Mentel M, van Hellemond JJ, Henze K, Woehle C, Gould SB, et al, Biochemistry and evolution of anaerobic energy metabolism in eukaryotes. Microbiol Mol Biol Rev. 2012;76:444-95.

67. Warren LG, Guevara A. Nematode metabolism with special reference to Ancylostoma caninum. Rev Biol Trop. 1962;10:149-59.

68. Warren LG. Biochemistry of the dog hookworm. I. Oxidative metabolism Exp Parasitol. 1965;17:1-19.

69. Warren LG. Biochemistry of the dog hookworm. 3. Oxidative phosphorylation. Exp Parasitol. 1970;27:417-23.

70. Schad GA, Chowdhury AB, Dean CG, Kochar VK, Nawalinski TA, Thomas J, et al. Arrested development in human hookworm infections: an adaptation to a seasonally unfavorable external environment. Science. 1973;180:502-4.

71. Tissenbaum HA, Hawdon J, Perregaux M, Hotez P, Guarente L, Ruvkun G. A common muscarinic pathway for diapause recovery in the distantly related nematode species Caenorhabditis elegans and Ancylostoma caninum. Proc Natl Acad Sci USA. 2000:97:460-5.

72. Hotez P, Hawdon J, Schad GA. Hookworm larval infectivity, arrest and amphiparatenesis: the Caenorhabditis elegans Daf-c paradigm. Parasitol Today. 1993;9:23-6.

73. Dryanovski DI, Dowling C, Gelmedin V, Hawdon JM. RNA and protein synthesis is required for Ancylostoma caninum larval activation. Vet Parasitol. 2011:179:137-43.

74. Hawdon JM, Datu B. The second messenger cyclic GMP mediates activation in Ancylostoma caninum infective larvae. Int J Parasitol. 2003;33:787-93.

75. Constantinoiu CC, Goullet MS, Constantinoiu EC, Scott JL. Mucosal tolerance of the hookworm Ancylostoma caninum in the gut of naturally infected wild dogs. Parasite Immunol. 2015:37:510-20.

76. Mulvenna J, Hamilton B, Nagaraj SH, Smyth D, Loukas A, Gorman JJ. Proteomics analysis of the excretory/secretory component of the blood-feeding stage of the hookworm, Ancylostoma caninum. Mol Cell Proteomics. 2009:8:109-21.

77. Ruyssers NE, De Winter BY, De Man JG, Loukas A, Pearson MS, Weinstock JV, et al. Therapeutic potential of helminth soluble proteins in TNBS-induced colitis in mice. Inflamm Bowel Dis. 2009;15:491-500.

78. Moyle M, Foster DL, McGrath DE, Brown SM, Laroche Y, De Meutter J, et al. A hookworm glycoprotein that inhibits neutrophil function is a ligand of the integrin CD11b/CD18. J Biol Chem. 1994;269:10008-15.

79. Tribolet L, Cantacessi C, Pickering DA, Navarro S, Doolan DL, Trieu A, et al. Probing of a human proteome microarray with a recombinant pathogen protein reveals a novel mechanism by which hookworms suppress B-cell receptor signaling. J Infect Dis. 2015;211:416-25.

80. Navarro S, Pickering DA, Ferreira IB, Jones L, Ryan S, Troy S, et al. Hookworm recombinant protein promotes regulatory $T$ cell responses that suppress experimental asthma. Sci Transl Med. 2016;8:362ra143.

81. Bowman DD, Montgomery SP, Zajac AM, Eberhard ML, Kazacos KR. Hookworms of dogs and cats as agents of cutaneous larva migrans. Trends Parasitol. 2010;26:162-7.

82. Heukelbach J, Feldmeier H. Epidemiological and clinical characteristics of hookworm-related cutaneous larva migrans. Lancet. 2008;8:302-9.
83. Kwon IH, Kim HS, Lee JH, Choi MH, Chai JY, Nakamura-Uchiyama F, et al. A serologically diagnosed human case of cutaneous larva migrans caused by Ancylostoma caninum. Korean J Parasitol. 2003;41:233-7.

84. Lee KT, Little MD, Beaver PC. Intracellular (Muscle-Fiber) habitat of Ancylostoma caninum in some mammalian hosts. J Parasitol. 1975;61: 589-98.

85. Little MD, Halsey NA, Cline BL, Katz SP. Ancylostoma larva in a muscle fiber of man following cutaneous larva migrans. Am J Trop Med Hyg. 1983;32:1285-8.

86. Croese J, Loukas A, Opdebeeck J, Fairley S, Prociv P. Human enteric infection with canine hookworms. Ann Intern Med. 1994;120:369-74.

87. Walker NI, Croese J, Clouston AD, Parry M, Loukas A, Prociv P. Eosinophilic enteritis in northeastern Australia. Pathology, association with Ancylostoma caninum, and implications. Am J Surg Pathol. 1995;19:328-37.

88. Haçarız O, Sayers GP. The omic approach to parasitic trematode research - a review of techniques and developments within the past 5 years. Parasitol Res. 2016;115:2523-43.

89. Preidis GA, Hotez PJ. The newest "omics" - metagenomics and metabolomics - enter the battle against the neglected tropical diseases. PLoS Negl Trop Dis. 2015;9(2):e0003382.

90. Wang Z, Abubucker S, Martin J, Wilson RK, Hawdon J, Mitreva M. Characterizing Ancylostoma caninum transcriptome and exploring nematode parasitic adaptation. BMC Genomics. 2010;11:307.

91. Korhonen PK, Young ND, Gasser RB. Making sense of genomes of parasitic worms: Tackling bioinformatic challenges. Biotechnol Adv. 2016;34:663-86

92. Morante T, Shepherd C, Constantinoiu C, Loukas A, Sotillo J. Revisiting the Ancylostoma caninum secretome provides new information on hookwormhost interactions. Proteomics. 2017. https://doi.org/10.1002/pmic.201700186.

93. Tang YT, Gao X, Rosa BA, Abubucker S, Hallsworth-Pepin K, Martin J, et al. Genome of the human hookworm Necator americanus. Nat Genet. 2014;46:261-9.

94. Jex AR, Waeschenbach A, Hu M, van Wyk JA, Beveridge I, Littlewood DT, et al. The mitochondrial genomes of Ancylostoma caninum and Bunostomum phlebotomum - two hookworms of animal health and zoonotic importance. BMC Genomics. 2009;10:79.

95. Hu M, Chilton NB, Zhu X, Gasser RB. Single-strand conformation polymorphism-based analysis of mitochondrial cytochrome c oxidase subunit 1 reveals significant substructuring in hookworm populations. Electrophoresis. 2002;23:27-34.

96. Ng-Nguyen D, Hii SF, Nguyen VA, Van Nguyen T, Van Nguyen D, Traub RJ. Re-evaluation of the species of hookworms infecting dogs in central Vietnam. Parasit Vectors. 2015;8(1):1-6.

97. Traub RJ, Robertson ID, Irwin P, Mencke N, Thompson RC. Application of a species-specific PCR-RFLP to identify Ancylostoma eggs directly from canine faeces. Vet Parasitol. 2004;123:245-55.

98. Hu M, Chilton NB, Abs El-Osta YG, Gasser RB. Comparative analysis of mitochondrial genome data for Necator americanus from two endemic regions reveals substantial genetic variation. Int J Parasitol. 2003;33:955-63.

99. Romstad A, Gasser RB, Nansen P, Polderman AM, Chilton NB. Necator americanus (Nematoda: Ancylostomatidae) from Africa and Malaysia have different ITS-2 rDNA sequences. Int J Parasitol. 1998;28:611-5.

100. Tyagi R, Rosa BA, Lewis WG, Mitreva M. Pan-phylum comparison of nematode metabolic potential. PLoS Negl Trop Dis. 2015;9(5):e0003788.

101. Jeelani G, Nozaki T. Metabolomic analysis of Entamoeba: applications and implications. Curr Opin Microbiol. 2014;20:118-24.

102. Loftus B, Anderson I, Davies R, Alsmark UC, Samuelson J, Amedeo P, et al. The genome of the protist parasite Entamoeba histolytica. Nature. 2005:433:865-8

103. Noverr MC, Erb-Downward JR, Huffnagle GB. Production of eicosanoids and other oxylipins by pathogenic eukaryotic microbes. Clin Microbiol Rev. 2003:16:517-33.

104. Wang Q, Heizer E, Rosa BA, Wildman SA, Janetka JW, Mitreva M. Characterization of parasite-specific indels and their proposed relevance for selective anthelminthic drug targeting. Infect Genet Evol. 2016;39:201-11.

105. Gruber FP, Hartung T. Alternatives to animal experimentation in basic research. ALTEX. 2004;21(Suppl. 1):3-31.

106. Fujiwara RT, Geiger SM, Bethony J, Mendez S. Comparative immunology of human and animal models of hookworm infection. Parasite Immunol. 2006;28:285-93. 
107. Loukas A, Prociv P. Immune responses in hookworm infections. Clin Microbiol Rev. 2001;14:689-703.

108. Griffiths GD, Brown AP, Hooi DS, Pearce PC, Hornby RJ, Scott L, et al. Development of a model of hookworm infection exhibiting salient characteristics of human infection. Am J Trop Med Hyg. 2008; 78:936-45.

109. Loukas A, Hotez PJ, Diemert D, Yazdanbakhsh M, McCarthy JS, Correa-Oliveira R, et al. Hookworm infection. Nat Rev Dis Primers. 2016;2:16088

110. Sotillo J, Sanchez-Flores A, Cantacessi C, Harcus Y, Pickering D, Bouchery T, et al. Secreted proteomes of different developmental stages of the gastrointestinal nematode Nippostrongylus brasiliensis. Mol Cell Proteomics. 2014;13:2736-51.

111. Camberis M, Le Gros G, Urban J Jr. Animal model of Nippostrongylus brasiliensis and Heligmosomoides polygyrus. Chapter 19:Unit 19.12. In: Coligan JE, et al., editors. Current protocols in immunology. Wiley online; 2003.

112. Balic A, Harcus Y, Holland MJ, Maizels RM. Selective maturation of dendritic cells by Nippostrongylus brasiliensis-secreted proteins drives Th2 immune responses. Eur J Immunol. 2004;34:3047-59.

113. Notari L, Riera DC, Sun R, Bohl JA, McLean LP, Madden KB, et al. Role of macrophages in the altered epithelial function during a type 2 immune response induced by enteric nematode infection. PLoS One. 2014;9(1): e84763.

114. Valanparambil RM, Segura M, Tam M, Jardim A, Geary TG, Stevenson MM. Production and analysis of immunomodulatory excretory-secretory products from the mouse gastrointestinal nematode Heligmosomoides polygyrus bakeri. Nat Protoc. 2014;9:2740-54.

115. Harris NL, Pleass R, Behnke JM. Understanding the role of antibodies in murine infections with Heligmosomoides (polygyrus) bakeri: 35 years ago, now and 35 years ahead. Parasite Immunol. 2014;36:115-24.

116. Behnke JM. Evasion of immunity by nematode parasites causing chronic infections. Adv Parasitol. 1987;26:1-71.

117. Maizels RM, Yazdanbakhsh M. Immune regulation by helminth parasites: cellular and molecular mechanisms. Nat Rev Immunol. 2003;3:733-44.

118. Grencis RK, Humphreys NE, Bancroft AJ. Immunity to gastrointestinal nematodes: mechanisms and myths. Immunol Rev. 2014;260:183-205.

119. Zaph C, Cooper PJ, Harris NL. Mucosal immune responses following intestinal nematode infection. Parasite Immunol. 2014;36:439-52.

120. Xue J, Hui-Qing Q, Jun-Ming Y, Fujiwara R, Zhan B, Hotez P, et al. Necator americanus: optimization of the golden hamster model for testing anthelmintic drugs. Exp Parasitol. 2005;111:219-23.

121. Jian X, Sen L, Hui-Qin Q, Hai-Nan R, Tie-Hua L, Hai-Chou X, et al. Necator americanus: maintenance through one hundred generations in golden hamsters (Mesocricetus auratus). I. Host sex-associated differences in hookworm burden and fecundity. Exp Parasitol. 2003;104:62-6.

122. Jian X, Shu-Hua X, Hui-Qing Q, Sen L, Hotez P, Bing-Gui S, et al. Necator americanus: maintenance through one hundred generations in golden hamsters (Mesocricetus auratus). II. Morphological development of the adult and its comparison with humans. Exp Parasitol. 2003:105:192-200.

123. Bungiro RD Jr, Anderson BR, Cappello M. Oral transfer of adult Ancylostoma ceylanicum hookworms into permissive and nonpermissive host species. Infect Immun. 2003;71:1880-6.

124. Alkazmi L, Behnke JM. The mucosal response to secondary infection with Ancylostoma ceylanicum in hamsters immunized by abbreviated primary infection. Parasite Immunol. 2010;32:47-56.

125. Cuéllar C, Wu W, Mendez S. The hookworm tissue inhibitor of metalloproteases (Ac-TMP-1) modifies dendritic cell function and induces generation of CD4 and CD8 suppressor T cells. PLoS Negl Trop Dis. 2009;3(5):e439.

126. Geiger SM, Fujiwara RT, Santiago H, Correa-Oliveira R, Bethony JM. Early stage-specific immune responses in primary experimental human hookworm infection. Microbes Infect. 2008;10:1524-35.

127. Ricci ND, Fiuza JA, Bueno LL, Cancado GG, Gazzinelli-Guimaraes PH, Martins VG, et al. Induction of CD4+CD25+FOXP3+ regulatory $T$ cells during human hookworm infection modulates antigen-mediated lymphocyte proliferation. PLoS Negl Trop Dis. 2011;5(11):e1383.

128. Maxwell C, Hussain R, Nutman TB, Poindexter RW, Little MD, Schad GA, et al. The clinical and immunologic responses of normal human volunteers to low dose hookworm (Necator americanus) infection. Am J Trop Med Hyg. 1987;37:126-34.

129. Sen HG, Seth D. Development of Necator americanus in golden hamsters Mesocricetus auratus. Indian J Med Res. 1970;58:1356-60.
130. Cantacessi C, Mitreva M, Jex AR, Young ND, Campbell BE, Hall RS, et al. Massively parallel sequencing and analysis of the Necator americanus transcriptome. PLoS Negl Trop Dis. 2010;4(5):e684.

131. Li T-H, Guo X-R, Xue J, Hu L, Qiang H-Q, Xue H-C, et al. Comparison of mitochondrial cytochrome oxidase 1 DNA sequences from Necator americanus hookworms maintained for 100 generations in golden hamsters (Mesocricetus auratus) and hookworms from natural human infections. Acta Trop. 2004;92:71-5.

132. Hsieh GC, Loukas A, Wahl AM, Bhatia M, Wang Y, Williamson AL, et al. A secreted protein from the human hookworm Necator americanus binds selectively to NK cells and induces IFN-gamma production. J Immunol. 2004;173:2699-704.

133. Flores D, Panic G, Braissant O, Keiser J. A novel isothermal microcalorimetry tool to assess drug effects on Ancylostoma ceylanicum and Necator americanus. Appl Microbiol Biotechnol. 2016:100:837-46.

134. Mcsorley HJ, Loukas A. The immunology of human hookworm infections. Parasite Immunol. 2010;32:549-59.

135. Jian X, Shu-Hua X, Hui-qing Q, Sen L, Hotez P, Bing-Gui S, et al. Necator americanus: maintenance through one hundred generations in golden hamsters (Mesocricetus auratus). II. Morphological development of the adult and its comparison with humans. Exp Parasitol. 2003;105:192-200.

136. Jiang D, Zhan B, Mayor RS, Gillespie P, Keegan B, Bottazzi ME, et al. Ac-AP12, a novel factor Xa anticoagulant peptide from the esophageal glands of adult Ancylostoma caninum. Mol Biochem Parasitol. 2011;177:42-8.

137. Don TA, Jones MK, Smyth D, O'Donoghue P, Hotez P, Loukas AA. pore-forming haemolysin from the hookworm, Ancylostoma caninum. Int J Parasitol. 2004;34: 1029-35.

138. Basavaraju SV, Zhan B, Kennedy MW, Liu Y, Hawdon J, Hotez PJ. Ac-FAR-1, a $20 \mathrm{kDa}$ fatty acid- and retinol-binding protein secreted by adult Ancylostoma caninum hookworms: gene transcription pattern, ligand binding properties and structural characterisation. Mol Biochem Parasitol. 2003;126:63-71.

139. Ferreira I, Smyth D, Gaze S, Aziz A, Giacomin P, Ruyssers N, et al. Hookworm excretory/secretory products induce interleukin-4 (IL-4)+ IL-10+ CD4+ T cell responses and suppress pathology in a mouse model of colitis. Infect Immun. 2013;81:2104-11.

140. Chhabra S, Chang SC, Nguyen HM, Huq R, Tanner MR, Londono LM, et al. Kv1.3 channel-blocking immunomodulatory peptides from parasitic worms: implications for autoimmune diseases. FASEB J. 2014;28:3952-64.

141. Kemmer A, Bieber K, Abadpour A, Yu X, Mitschker N, Roth S, et al. A recombinant fusion protein derived from dog hookworm inhibits autoantibody-induced dermal-epidermal separation ex vivo. Exp Dermatol. 2015:24:872-8.

142. Cancado GG, Fiuza JA, de Paiva NC, Lemos Lde C, Ricci ND, Gazzinelli-Guimaraes $\mathrm{PH}$, et al. Hookworm products ameliorate dextran sodium sulfate-induced colitis in BALB/c mice. Inflamm Bowel Dis. 2011;17:2275-86.

143. Schad GA. Ancylostoma duodenale: maintenance through six generations in helminth-native pups. Exp Parasitol. 1979;47:246-53.

144. Leiby DA, el Naggar HM, Schad GA. Thirty generations of Ancylostoma duodenale in laboratory-reared beagles. J Parasitol. 1987;73:844-8.

145. Boag PR, Parsons JC, Presidente PJ, Spithill TW, Sexton JL. Characterisation of humoral immune responses in dogs vaccinated with irradiated Ancylostoma caninum. Vet Immunol Immunopathol. 2003;92:87-94.

146. Miller TA. Industrial development and field use of the canine hookworm vaccine. Adv Parasitol. 1978;16:333-42.

147. Fujiwara RT, Loukas A, Mendez S, Williamson AL, Bueno LL, Wang Y, et al. Vaccination with irradiated Ancylostoma caninum third stage larvae induces a Th2 protective response in dogs. Vaccine. 2006;24:501-9.

148. Loukas A, Bethony J, Brooker S, Hotez P. Hookworm vaccines: past, present, and future. Lancet Infect Dis. 2006;6:733-41.

149. Pang T. Equal partnership to ensure that developing countries benefit from genomics. Nat Genet. 2003;33:18

150. Fathalla M. Tapping the potential for health research in developing countries. Bull World Health Organ. 2004;82(10):722.

151. Traub RJ. Ancylostoma ceylanicum, a re-emerging but neglected parasitic zoonosis. Int J Parasitol. 2013:43:1009-15.

152. Smout FA, Thompson RC, Skerratt LF. First report of Ancylostoma ceylanicum in wild canids. Int J Parasitol Parasites Wildl. 2013;2:173-7.

153. Wei J, Damania A, Gao X, Liu Z, Mejia R, Mitreva M, et al. The hookworm Ancylostoma ceylanicum intestinal transcriptome provides a platform for selecting drug and vaccine candidates. Parasit Vectors. 2016;9(1):518. 
154. Carroll SM, Grove DI. Parasitological, hematologic, and immunologic responses in acute and chronic infections of dogs with Ancylostoma ceylanicum: a model of human hookworm infection. J Infect Dis. 1984;150:284-94.

155. Ngui R, Lim YA, Traub R, Mahmud R, Mistam MS. Epidemiological and genetic data supporting the transmission of Ancylostoma ceylanicum among human and domestic animals. PLoS Negl Trop Dis. 2012;6(2):e1522.

156. Dorris M, De Ley P, Blaxter ML. Molecular analysis of nematode diversity and the evolution of parasitism. Parasitol Today. 1999;15:188-93.

157. Hewitson JP, Grainger JR, Maizels RM. Helminth immunoregulation: The role of parasite secreted proteins in modulating host immunity. Mol Biochem Paraitol. 2009;167:1-11.

158. Harnett W, Harnett MM. Immunomodulatory activity and therapeutic potential of the filarial nematode secreted product, ES-62. Adv Exp Med Biol. 2009;666:88-94.

159. S-H Y, Jiang Z-X, Xu L-Q. Infantile hookworm disease in China. A review. Acta Trop. 1995;59:265-70.

160. Prociv $P$, Luke RA. Evidence for larval hypobiosis in Australian strains of Ancylostoma duodenale. Trans R Soc Trop Med Hyg. 1995;89:379.

161. Food and Agriculture Organization of the United Nations. Multicriteriabased ranking for risk management of food-borne parasites, Microbiological Risk Management Series, vol. 23; 2014. p. 302. Rome

162. Arasu P, Heller A. Antibody responses in pregnancy-induced transmammary transmission of Ancylostoma caninum hookworm larvae. Vet Immunol Immunopathol. 1999;70:289-98.

163. Liu Y, Zheng G, Alsarakibi M, Zhang X, Hu W, Lu P, et al. Molecular identification of Ancylostoma caninum isolated from cats in southern China based on complete ITS sequence. Biomed Res Int. 2013;2013:6.

164. Phosuk I, Intapan PM, Thanchomnang T, Sanpool O, Janwan P, Laummaunwai $P$, et al. Molecular detection of Ancylostoma duodenale, Ancylostoma ceylanicum, and Necator americanus in humans in northeastern and southern Thailand. Korean J Parasitol. 2013;51:747-9.

165. Traub RJ, Inpankaew T, Sutthikornchai C, Sukthana Y, Thompson RC. PCR-based coprodiagnostic tools reveal dogs as reservoirs of zoonotic ancylostomiasis caused by Ancylostoma ceylanicum in temple communities in Bangkok. Vet Parasitol. 2008;155:67-73.

166. Tawin I, Fabian S, Anders D, Virak K, Wissanuwat C, Chamnan C, et al. High prevalence of Ancylostoma ceylanicum hookworm infections in humans, Cambodia, 2012. Emerg Infect Dis. 2014:20:976.

167. Miller TA. Vaccination against the canine hookworm diseases. Adv Parasitol. 1971:9:153-83.

168. Dunbar MR, McLaughlin GS, Murphy DM, Cunningham MW. Pathogenicity of the hookworm, Ancylostoma pluridentatum, in a Florida panther (Felis concolor coryi) kitten. J Wildl Dis. 1994;30:548-51.

169. Cames T, Forrester D. The geographic distributions of Ancylostoma pluridentatum and other hookworms in bobcats (Felis rufus) from Florida. Florida Field Naturalist. 1998;26:18-20.

170. Norris DE. The migratory behavior of the infective-stage larvae of Ancylostoma braziliense and Ancylostoma tubaeforme in rodent paratenic hosts. J Parasitol. 1971;57:998-1009.

171. Vicente J, Palomares F, Ruiz de Ibanez R, Ortiz J. Epidemiology of Ancylostoma spp. in the endangered Iberian lynx (Lynx pardinus) in the Doñana National Park, south-west Spain. J Helminthol. 2004;78:179-83.

172. Yoshida Y. Ancylostoma kusimaense from a dog in Japan and comparative morphology of related ancylostomes. J Parasitol. 1965;51:631-5.

173. Macchioni G. Ancylostoma genettae, A. protelesis, A. somaliense: three new species from wild Carnivora in the Somali Republic. Parassitologia. 1995;37:219-28

174. Brooker S, Bethony J, Hotez PJ. Human hookworm infection in the $21 \mathrm{st}$ Century. Adv Parasitol. 2004;58:197-288.

175. Hasegawa H, Modry D, Kitagawa M, Shutt KA, Todd A, Kalousova B, et al. Humans and great apes cohabiting the forest ecosystem in central african republic harbour the same hookworms. PLoS Negl Trop Dis. 2014;8(3):e2715.

176. Kalousova B, Hasegawa H, Petrzelkova KJ, Sakamaki T, Kooriyma T, Modry D. Adult hookworms (Necator spp.) collected from researchers working with wild western lowland gorillas. Parasit Vectors. 2016;9(1):75.

177. Mackenstedt $U$, Jenkins $D$, Romig T. The role of wildlife in the transmission of parasitic zoonoses in peri-urban and urban areas. Int J Parasitol Parasites Wildl. 2015:4:71-9.

178. C. elegans Sequencing Consortium. Genome sequence of the nematode C. elegans: a platform for investigating biology. Science. 1998;282:2012-8.
179. Hillier LW, Coulson A, Murray JI, Bao Z, Sulston JE, Waterston RH. Genomics in C. elegans: So many genes, such a little worm. Genome Res. 2005;15:1651-60.

180. Kim SK, Lund J, Kiraly M, Duke K, Jiang M, Stuart JM, et al. A gene expression map for Caenorhabditis elegans. Science. 2001;293:2087-92.

181. Mckay SJ, Johnsen R, Khattra J, Asano J, Baillie DL, Chan S, et al. Gene expression profiling of cells, tissues, and developmental stages of the nematode C. elegans. Cold Spring Harb Symp Quant Biol. 2003;68:159-69.

182. He H, Wang J, Liu T, Liu XS, Li T, Wang Y, et al. Mapping the C. elegans noncoding transcriptome with a whole-genome tiling microarray. Genome Res. 2007;17:1471-7.

183. Deng W, Zhu X, Skogerbo G, Zhao Y, Fu Z, Wang Y, et al. Organization of the Caenorhabditis elegans small non-coding transcriptome: genomic features, biogenesis, and expression. Genome Res. 2006;16:20-9.

184. Wang Y, Chen J, Wei G, He H, Zhu X, Xiao T, et al. The Caenorhabditis elegans intermediate-size transcriptome shows high degree of stagespecific expression. Nucleic Acids Res. 2011;39:5203-14.

185. Yuet KP, Doma MK, Ngo JT, Sweredoski MJ, Graham RL, Moradian A, et al. Cell-specific proteomic analysis in Caenorhabditis elegans. Proc Natl Acad Sci USA. 2015;112:2705-10.

186. Hunt-Newbury R, Viveiros R, Johnsen R, Mah A, Anastas D, Fang $L$, et al. High-throughput in vivo analysis of gene expression in Caenorhabditis elegans. PLoS Biol. 2007:5(9):e237.

187. Bensaddek D, Narayan V, Nicolas A, Brenes Murillo A, Gartner A, Kenyon CJ, Lamond Al. Micro-proteomics with iterative data analysis: Proteome analysis in C. elegans at the single worm level. Proteomics. 2016;16:381-92.

188. Ranjit N, Jones MK, Stenzel DJ, Gasser RB, Loukas A. A survey of the intestinal transcriptomes of the hookworms, Necator americanus and Ancylostoma caninum, using tissues isolated by laser microdissection microscopy. Int J Parasitol. 2006;36:701-10.

189. Daub J, Loukas A, Pritchard DI, Blaxter M. A survey of genes expressed in adults of the human hookworm, Necator americanus. Parasitology. 2000;120:171-84

190. Kumar S, Pritchard DI. The partial characterization of proteases present in the excretory/secretory products and exsheathing fluid of the infective (L3) larva of Necator americanus. Int J Parasitol. 1992;22: 563-72.

191. Pritchard DI, Leggett KV, Rogan MT, McKean PG, Brown A. Necator americanus secretory acetylcholinesterase and its purification from excretory-secretory products by affinity chromatography. Parasite Immunol. 1991;13:187-99.

192. Rabelo EM, Hall RS, Loukas A, Cooper L, Hu M, Ranganathan S, et al. Improved insights into the transcriptomes of the human hookworm Necator americanus - fundamental and biotechnological implications. Biotechnol Adv. 2009;27:122-32.

193. Mitreva M, McCarter JP, Arasu P, Hawdon J, Martin J, Dante M, et al. Investigating hookworm genomes by comparative analysis of two Ancylostoma species. BMC Genomics. 2005;6:58.

194. Abubucker S, Martin J, Yin Y, Fulton L, Yang S-P, Hallsworth-Pepin K, et al. The canine hookworm genome: analysis and classification of Ancylostoma caninum survey sequences. Mol Biochem Parasitol. 2008; 157:187-92.

195. Datu BJD, Gasser RB, Nagaraj SH, Ong EK, O'Donoghue P, Mcinnes R, et al. Transcriptional changes in the hookworm, Ancylostoma caninum, during the transition from a free-living to a parasitic larva. PLoS Negl Trop Dis. 2008;2(1):e130.

196. Schwarz EM, Hu Y, Antoshechkin I, Miller MM, Sternberg PW, Aroian RV. The genome and transcriptome of the zoonotic hookworm Ancylostoma ceylanicum identify infection-specific gene families. Nat Genet. 2015; 47:416-22.

197. Costa AF, Gomes-Ruiz AC, Rabelo EM. Identification of gender-regulated genes in Ancylostoma braziliense by real-time RT-PCR. Vet Parasitol. 2008;153: 277-84

198. Ghedin E, Wang S, Spiro D, Caler E, Zhao Q, Crabtree J, et al. Draft genome of the filarial nematode parasite Brugia malayi. Science. 2007; 317:1756-60.

199. Choi YJ, Ghedin E, Berriman M, McQuillan J, Holroyd N, Mayhew GF, et al. A deep sequencing approach to comparatively analyze the transcriptome of life-cycle stages of the filarial worm, Brugia malayi. PLoS Negl Trop Dis. 2011;5(12):e1409. 
200. Moreno Y, Geary TG. Stage- and gender-specific proteomic analysis of Brugia malayi excretory-secretory products. PLoS Negl Trop Dis. 2008;2(10):e326.

201. Hewitson JP, Harcus YM, Curwen RS, Dowle AA, Atmadja AK, Ashton PD, et al. The secretome of the filarial parasite, Brugia malayi: proteomic profile of adult excretory-secretory products. Mol Biochem Parasitol. 2008;160:8-21.

202. Morris CP, Bennuru S, Kropp LE, Zweben JA, Meng Z, Taylor RT, et al. A proteomic analysis of the body wall, digestive tract, and reproductive tract of Brugia malayi. PLoS Negl Trop Dis. 2015;9(9): e0004054.

203. Scott A, Ghedin E. The genome of Brugia malayi - all worms are not created equal. Parasitol Int. 2009;58:6-11.

204. Reynolds LA, Filbey KJ, Maizels RM. Immunity to the model intestinal helminth parasite Heligmosomoides polygyrus. Semin Immunol. 2012;34: 829-46.

205. Hewitson JP, Harcus Y, Murray J, van Agtmaal M, Filbey KJ, Grainger $J R$, et al. Proteomic analysis of secretory products from the model gastrointestinal nematode Heligmosomoides polygyrus reveals dominance of venom allergen-like (VAL) proteins. J Proteome. 2011; 74:1573-94.

206. Maizels RM, Hewitson JP, Murray J, Harcus YM, Dayer B, Filbey K, et al. Immune modulation and modulators in Heligmosomoides polygyrus infection. Exp Parasitol. 2012;132:76-89.

207. Camberis M, Le Gros G, Urban J. Animal model of Nippostrongylus brasiliensis and Heligmosomoides polygyrus. In: Coligan JE, et al., editors. Current protocols in immunology; 2001. Wiley online.

208. Monroy FG, Enriquez FJ. Heligmosomoides polygyrus: a model for chronic gastrointestinal helminthiasis. Parasitol Today. 1992;8:49-54.

209. Chen F, Wu W, Millman A, Craft JF, Chen E, Patel N, et al. Neutrophils prime a long-lived effector macrophage phenotype that mediates accelerated helminth expulsion. Nat Immunol. 2014;15:938-46.

210. Shim DS, Schilter HC, Knott ML, Almeida RA, Short RP, Mackay CR, et al. Protection against Nippostrongylus brasiliensis infection in mice is independent on GM-CSF. Immunol Cell Biol. 2012;90:553-8.

211. Giacomin PR, Wang H, Gordon DL, Botto M, Dent LA. Loss of complement activation and leukocyte adherence as Nippostrongylus brasiliensis develops within the murine host. Infect Immun. 2005;73:7442-9.

212. Wescott RB, Todd AC. Adaptation of Nippostrongylus brasiliensis to the mouse. J Parasitol. 1966;52:233-6.

213. Mendez S, Valenzuela JG, Wu W, Hotez PJ. Host cytokine production, lymphoproliferation, and antibody responses during the course of Ancylostoma ceylanicum infection in the golden syrian hamster. Infect Immun. 2005;73:3402-7.

214. Bungiro RD, Greene J, Kruglov E, Cappello M. Mitigation of hookworm disease by immunization with soluble extracts of Ancylostoma ceylanicum. J Infect Dis. 2001;183:1380-7.

215. Xue J, Zhan B, Guo J, He N, Qiang HQ, Hotez P, et al. Acquired hookworm immunity in the golden hamster (Mesocricetus auratus) elicited by living Necator americanus third-stage infective larvae. Exp Parasitol. 2012:130:6-12.

216. Detection without physical examination of whipworms and hookworms including eggs and larvae. U.S. Food and Drug Administration; 2017. http://www.accessdata.fda.gov/cms_ia/importalert_159.html.

\section{Submit your next manuscript to BioMed Central and we will help you at every step:}

- We accept pre-submission inquiries

- Our selector tool helps you to find the most relevant journal

- We provide round the clock customer support

- Convenient online submission

- Thorough peer review

- Inclusion in PubMed and all major indexing services

- Maximum visibility for your research

Submit your manuscript at www.biomedcentral.com/submit
Biomed Central 